\title{
Potential of Chitosan for the Control of Tomato Bacterial Wilt Caused by Ralstonia solanacearum (Smith) Yabuuchi et al
}

\author{
Lucia M. Borines ${ }^{1}$, Rezel M. Sagarino ${ }^{1}$, Rosario B. Calamba ${ }^{1}$, Ma. \\ Angelica A. Contioso', Jacob Glenn F. Jansalin ${ }^{2}$ and Candelario \\ L. Calibo ${ }^{2}$
}

${ }^{1}$ Department of Pest Management, and ${ }^{2}$ Department of Pure and Applied Chemistry, Visayas State University, Visca, Baybay City, Leyte, Philippines

\section{ABSTRACT}

Bacterial wilt is an important constraint to tomato production. The search for an effective and safe method of managing bacterial wilt is imperative. Chitosan, a deactylated chitin was reported to possess direct antimicrobial property against certain pathogens and is a plant resistance booster. This study was conducted to: evaluate the effectiveness of varying chitosan concentrations and sources against bacterial wilt in vitro and in vivo and compare different application methods in bacterial wilt control. Varying chitosan concentrations $(100,200,300,400$ and 500 ppm) immersed/dissolved in water, $1 \%$ acetic acid, and streptomycin were evaluated against $R$. solanacearum in laboratory and pot experiments. Three chitosan sources were also evaluated against the pathogen. Different methods of application were compared. Regardless of source, chitosan in water has no direct antimicrobial activity against $R$. solanacearum but when dissolved $1 \%$ acetic acid, it was able to inhibit the bacteria. Inhibition of chitosan/acetic acid was best at $300 \mathrm{ppm}$ and significantly higher than 1\% acetic acid alone indicating that its antimicrobial property was enhanced by the acid. Two hundred ppm chitosan/acetic acid-treated plants delayed the onset of disease and produced the lowest percentage infection, lowest disease severity rating, and highest percentage survival in inoculated tomato. The action of $200 \mathrm{ppm}$ chitosan/acetic acid treatment was due to a dual effect, i.e., antimicrobial and as an elicitor of resistance. All application methods were effective in controlling bacterial wilt but one time root dipping to $200 \mathrm{ppm}$ chitosan/acetic acid before transplanting was enough to protect the plants against the disease.

Keywords: Tomato, Bacteria, Wilt, Chitosan, Ralstonia

\section{INTRODUCTION}

Bacterial wilt of tomato caused by R. solanacearum [Smith (1986) Yabuuchi et al., (1996)] has long been a problem of tropical agriculture because the pathogen is very widely distributed and has an unusually broad host range. The symptoms appear as a drooping of one or more of the youngest leaves, a rapid "green" wilting of the foliage, then wilting, which is particularly noticeable during the warmest part of the day. Stunting may precede wilting and leaflets and leafstalks may curl downwards. Where the disease has developed slowly, more adventitious roots are produced along the stem above ground level (Persley et al., 2010).

Correspondence : L.M. Borines Address: Department of Pest Management, Visayas State University, Baybay City, 6521 Leyte, Philippines E-mail:lucyborines@gmail.com 
Ralstonia solanacearum is difficult to control because it is a soil-borne pathogen (Champoiseau et al., 2009). Economic loss due to bacterial wilt is greater in tomatoes than in any other crop especially during the rainy season (Hayward, 1985). Other than chemical fumigants which are highly toxic, there is no commercial pesticide available for the control of BW (Wang and Lin, 2005). The use of highly toxic chemicals can cause adverse effects to the applicators, non-target species, and the environment. There is therefore a need to search for alternative, non-toxic, and environment-friendly compounds that possess antimicrobial properties against the bacterial wilt pathogen.

Resistant cultivars are necessary for the control of bacterial wilt. The development of a resistant variety is time-consuming and incurs a huge amount of money. Certain compounds though are known to possess antimicrobial properties against selected pathogens and documented to induce resistance in normally susceptible plants by acting as a signal toward the activation of defense mechanism (Ryals et al., 2005). Chitosan, a polymer of $\beta$-1, 4-glucosamine residues, is a deactylated derivative of chitin which possesses antifungal properties and acts as a potent elicitor of plant resistance against fungal pathogens (Amborabe et al., 2008). Chitin is readily available from crustacean wastes from food processing. The chitosan molecule triggers a defense within the plant, leading to the formation of physical and chemical barriers against invading pathogens (Walker et al., 2004).

Chitosan was proven effective in protecting abaca from heart rot disease caused by Pectobacterium sp. (Niño, 2009), rice bacterial blight (Modina et al., 2009), and rice blast disease (Piamonte, 2010). Chitosan can be a potential antimicrobial agent against $R$. solanacearum or a resistance elicitor in tomato for the control of bacterial wilt. Different kinds/grades of chitosan are available in the market which may vary in their degree of effectiveness in controlling bacterial wilt. Effectiveness may also vary depending on the concentration used and methods of application to plants.

This study was conducted with the following objectives: to evaluate the antimicrobial property of different chitosan concentrations against Ralstonia solanacearum in vitro and in vivo; to evaluate the comparative efficacy of 3 chitosan sources against $R$. solanacearum; to evaluate its efficacy as elicitor of resistance in tomato bacterial wilt control; and to determine the effective application method for bacterial wilt control.

\section{MATERIALS AND METHODS}

\section{Preparation of Culture Media}

Two kinds of culture were used. The first one was composed of $10 \mathrm{~g}$ peptone, $5 \mathrm{~g}$ dextrose, $1 \mathrm{~g}$ casein hydrolysate, $15 \mathrm{~g}$ agar, and $1000 \mathrm{~mL}$ distilled water while the second medium was tetrazolium chloride agar (TCA) composed of the same components but added with $1 \mathrm{~mL}$ previously- sterilized triphenyl tetrazolium chloride $\left(0.5 \mathrm{~g} / 100 \mathrm{~mL} \mathrm{dH}_{2} \mathrm{O}\right)$ for every $100 \mathrm{~mL}$ medium cooled to $\sim 45^{\circ} \mathrm{C}$ just before pouring. The media were sterilized at $15 \mathrm{lbs} / \mathrm{in}^{2}$ for 15 minutes.

\section{Pathogen Isolation and Pathogenicity Test}

Bacterial wilt-infected tomato was collected from the experimental field of VSU. The specimens were brought to the Plant Disease Diagnostic Laboratory for pathogen isolation using standard isolation procedure for bacteria.

Pathogenicity of the isolates was conducted two times to healthy tomato seedlings (Improved Pope) to ascertain the virulence of the pathogen being used in the different experiments. A bacterial suspension was prepared and standardized to $1 \times 10^{8} \mathrm{cfu} / \mathrm{mL}$ and used to inoculate 3-week-old healthy tomato plants. In the first set of inoculation, one $\mathrm{mL}$ of the bacterial suspension was injected into the tomato stem. In the second pathogenicity 
test, small cuts were inflicted on the roots of tomato seedlings using sterile scissors and the roots were dipped into the suspension for 3 minutes before transplanting to sterile soil in polyethylene bags. The plants were observed daily for the development of typical wilting symptom. The isolates which caused severe wilting to the inoculated plants were kept for the succeeding experiments.

\section{Extraction of Chitosan}

Chitosan was extracted from crab exoskeleton using the procedure recommended by Bade and Wick (1988). The crustacean shells were collected from Orient Cold Storage Inc., Tacloban City, Leyte. Pulverized carapace was demineralized using 15\% (v/v) $\mathrm{HCl}$ in 1:10 solid/liquid ratio, deproteinized with $5 \%$ (w/v) $\mathrm{NaOH}$ and deacetylated with $50 \%$ (w/v) $\mathrm{NaOH}$ at $120^{\circ} \mathrm{C}$ for 8 hours. Surface morphology by scanning electron microscopy (SEM) and functional group analysis by Fourier transform-infrared (FT-IR) spectroscopy have verified chitosan properties produced in the laboratory run with Sigma AR chitosan as standard.

\section{In Vitro Evaluation of Antimicrobial Property of Different Chitosan Concentrations Against Ralstonia solanacearum}

A locally produced chitosan was used in this experiment. Different concentrations of chitosan dissolved in sterile distilled water $\left(\mathrm{dH}_{2} \mathrm{O}\right)$ and $1 \%$ acetic acid were prepared. For the chitosan/acetic acid, one gram of chitosan was dissolved in $1 \mathrm{~L}$ of $1 \%$ acetic acid solution to prepare $1000 \mathrm{ppm}$ stock solution. The different chitosan concentrations of 100 , $200,300,400$, and $500 \mathrm{ppm}$ at $500 \mathrm{~mL}$ each were prepared from the stock solution and were placed in separate containers until ready for use. The same concentrations of chitosan using water as solvent were also prepared.

The different chitosan concentrations in $\mathrm{dH}_{2} \mathrm{O}$ and acetic acid as solvent were bioassayed against $R$. solanacearum in vitro to determine if they have direct antimicrobial property against the pathogen. Ten $\mathrm{mL}$ sterile water was poured into a 48 -hour-old culture of the bacterium. The growth was aseptically scraped using a flamed- sterilized wire loop. One $\mathrm{mL}$ of $1 \times 10^{8} \mathrm{cfu} / \mathrm{mL}$ bacterial suspension was pipetted into a sterile Petri plate. Fourteen $\mathrm{mL}$ of a sterilized and melted medium which was cooled to $45^{\circ} \mathrm{C}$ was added into the suspension in the Petri plates. It was gently mixed with the suspension by thoroughly swirling the Petri plates until it started to solidify. Five $\mathrm{mm}$ diameter sterile filter paper discs were immersed into the different concentrations of chitosan and three sets of three layered discs were placed equidistantly on the inoculated plate. The plates were incubated at room temperature. The inhibition zone from the disc was measured at 2, 4, and 6 days after treatment. The treatments were the following: $\mathrm{T}_{0}$ - sterile water alone (negative control), $\mathrm{T}_{1^{-}}$ $100 \mathrm{ppm}$ chitosan $/ \mathrm{dH}_{2} \mathrm{O}, \mathrm{T}_{2^{-}} 200 \mathrm{ppm}$ chitosan $/ \mathrm{dH}_{2} \mathrm{O}, \mathrm{T}_{3-} 300 \mathrm{ppm}$ chitosan $/ \mathrm{dH}_{2} \mathrm{O}, \mathrm{T}_{4^{-}}$ $400 \mathrm{ppm}$ chitosan $/ \mathrm{dH}_{2} \mathrm{O}, \mathrm{T}_{5-} 500 \mathrm{ppm}$ chitosan $/ \mathrm{dH}_{2} \mathrm{O}, \mathrm{T}_{6}-100 \mathrm{ppm}$ chitosan/acetic acid, $\mathrm{T}_{7} 200 \mathrm{ppm}$ chitosan/acetic acid, $\mathrm{T}_{8^{-}} 300 \mathrm{ppm}$ chitosan/acetic acid, $\mathrm{T}_{9^{-}} 400 \mathrm{ppm}$ chitosan/acetic acid, $T_{10} 500 \mathrm{ppm}$ chitosan/acetic acid, $T_{11} .1 \%$ acetic acid alone, and $\mathrm{T}_{12} 300$ ppm streptomycin (positive control).

A second in vitro experiment was conducted using $200 \mathrm{ppm}$ of three chitosans from different sources, i.e., crab laboratory grade chitosan (Japan), crab laboratory grade chitosan (VSU), and crab commercial grade chitosan (China) (Figure 1). The same method of assay was used as in the first set-up. The treatments were the following: $\mathrm{T}_{1}$ - sterile $\mathrm{dH}_{2} \mathrm{O}$ (negative control), $\mathrm{T}_{2}-200 \mathrm{ppm}$ streptomycin (positive control), $\mathrm{T}_{3}-200 \mathrm{ppm}$ crab chitosan (Japan) $/ \mathrm{dH}_{2} \mathrm{O}, \mathrm{T}_{4^{-}} 200 \mathrm{ppm}$ crab chitosan (VSU) $/ \mathrm{dH}_{2} \mathrm{O}, \mathrm{T}_{5^{-}} 200 \mathrm{ppm}$ crab chitosan (China) $/ \mathrm{dH}_{2} \mathrm{O}, \mathrm{T}_{6}-200 \mathrm{ppm}$ crab chitosan (Japan)/acetic acid, $\mathrm{T}_{7^{-}} 200$ ppm crab chitosan (VSU)/acetic acid, $\mathrm{T}_{8^{-}} 200 \mathrm{ppm}$ crab chitosan (China)/acetic acid, and $\mathrm{T}_{9^{-}} 2000 \mathrm{ppm}$ $(0.2 \%)$ acetic acid alone. 


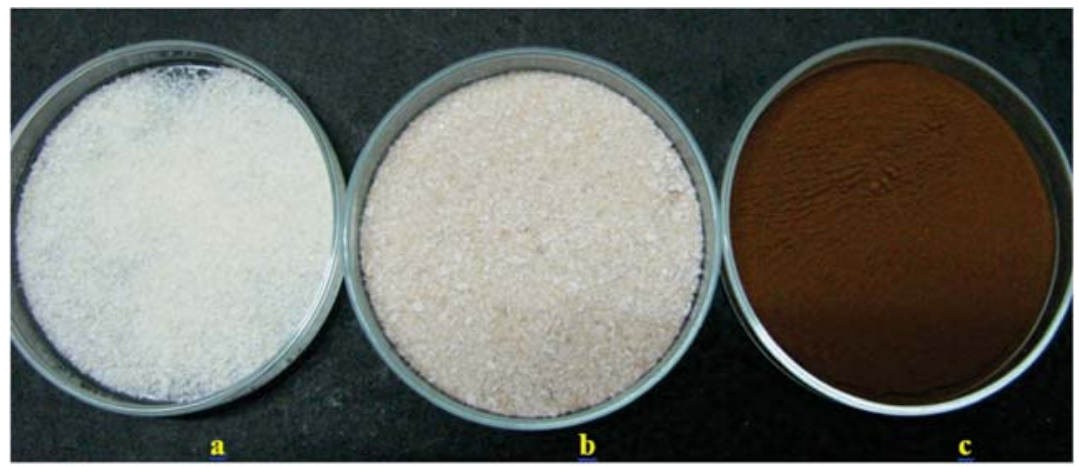

Figure 1. The three kinds of chitosan used in the experiment: (a) Laboratory grade crab chitosan [Japan], (b) Locally-produced crab chitosan [VSU] and (c) Commercial grade crab chitosan [China].

\section{In Vivo Evaluation of Different Chitosan Concentrations for Bacterial Wilt Control}

Tomato seeds were germinated in seedling trays with sterile soil and placed in the screenhouse. To apply the treatments, the seedlings were carefully uprooted, the roots were washed with water, small wounds were inflicted into the roots using sterile scissors, and the seedlings were dipped into the different treatments for 3 minutes. To inoculate the bacteria, the wounded roots were dipped for another 3 minutes into $10^{8} \mathrm{cfu} / \mathrm{mL}$ inoculum suspension before transplanting them in polyethylene pots at 10 plants per pot. VSU chitosan was used. The treatments were as follows: $\mathrm{T}_{0}$ - sterile $\mathrm{dH}_{2} \mathrm{O}$ (negative control), $\mathrm{T}_{1}$ $100 \mathrm{ppm}$ chitosan/ $\mathrm{dH}_{2} \mathrm{O}, \mathrm{T}_{2}-200 \mathrm{ppm}$ chitosan/ $\mathrm{dH}_{2} \mathrm{O}, \mathrm{T}_{3-} 300 \mathrm{ppm}$ chitosan/ $\mathrm{dH}_{2} \mathrm{O}, \mathrm{T}_{4}{ }^{-}$ $400 \mathrm{ppm}$ chitosan/ $\mathrm{dH}_{2} \mathrm{O}, \mathrm{T}_{5} 500 \mathrm{ppm}$ chitosan/ $\mathrm{dH}_{2} \mathrm{O}, \mathrm{T}_{6}-100 \mathrm{ppm}$ chitosan/acetic acid, $\mathrm{T}_{7 .} 200 \mathrm{ppm}$ chitosan/acetic acid, $\mathrm{T}_{8^{-}} 300 \mathrm{ppm}$ chitosan/acetic acid, $\mathrm{T}_{9^{-}} 400 \mathrm{ppm}$ chitosan/acetic acid, $\mathrm{T}_{10-} 500 \mathrm{ppm}$ chitosan/acetic acid, $\mathrm{T}_{11 .} 1 \%$ acetic acid alone, and $\mathrm{T}_{12} 300$ ppm streptomycin (positive control). The same treatments were repeatedly applied by spraying the test plants at weekly interval until most of the untreated plants in the control treatment have wilted.

The data gathered were: (a) incubation period of the disease (number of days from inoculation to the production of first visible symptoms); (b) percent infection; (c) disease severity rating using the rating scale: 1 [no wilting], 2 [slight wilting], 3 [moderate wilting], 4 [severe wilting] and 5 [plant is almost dead or dead; Figure 2], and (d) percent survival.

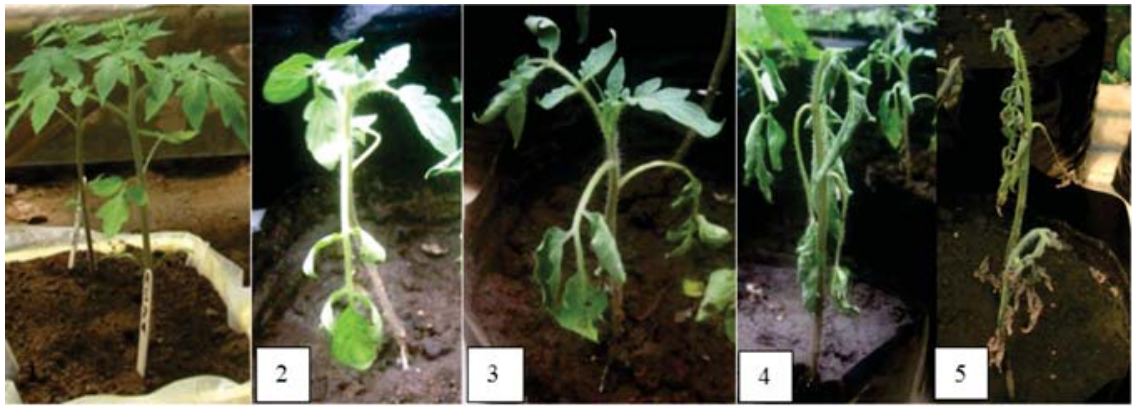

Figure 2. Physical appearance of the tomato plants with their respective diseases severity rating scale from 1 to 5 . 


\section{Evaluation of Effective Application Method for the Control of Bacterial Wilt}

Two hundred ppm of laboratory grade VSU crab chitosan was used in this experiment. The following were the treatments: $\mathrm{T}_{1-}$ sterile $\mathrm{dH}_{2} \mathrm{O}$ (negative control); $\mathrm{T}_{2}$ - chitosan/acetic acid, root dip once before transplanting; $\mathrm{T}_{3}$ - chitosan/acetic acid, drenched at weekly interval; $\mathrm{T}_{4}$ Chitosan/acetic acid sprayed at weekly interval; $\mathrm{T}_{5}$ - chitosan/acetic acid, root dip once and weekly drenched; $\mathrm{T}_{6}$ chitosan/acetic acid, root dip once and weekly spraying; $\mathrm{T}_{7}$ streptomycin, root dip once before transplanting $\mathrm{T}_{8}$ streptomycin, drenched at weekly interval; $\mathrm{T}_{9}$ - streptomycin, sprayed at weekly interval; $\mathrm{T}_{10}$ - streptomycin, root dip once and weekly drenched; $\mathrm{T}_{11^{-}}$- streptomycin, root dip once and weekly sprayed; and $\mathrm{T}_{12^{-}} 2000\left(0.2^{\%}\right)$ ppm acetic acid; root dip once and weekly sprayed. Inoculation of the pathogen was done as previously described. The data gathered were percent infection and percent survival.

\section{Statistical Design and Analysis}

All the experiments were laid in Completely Randomized Design (CRD) replicated three times. The treatment means were compared using the Tukey's Honest Significant Difference (HSD) test.

\section{RESULTS AND DISCUSSION}

\section{In vitro evaluation of the antimicrobialproperty of chitosan against Ralstonia solanacearum}

Chitosan immersed in $\mathrm{dH}_{2} \mathrm{O}$ at varying concentrations showed no direct antimicrobial property against $\mathrm{R}$. solanacearum in vitro at 2, 4, and 6 days after inoculation (DAI). No zones of inhibition were observed on the inoculated plates (Figure 3). Chitosan that were dissolved in 1\% acetic acid, however, produced clear zones of inhibition, with $300 \mathrm{ppm}$ chitosan/acetic acid producing the largest inhibition among the treatments. Its effect was however quite inferior to streptomycin, which produced the largest zone of inhibition (Table 1). One percent acetic acid alone showed direct antimicrobial action against $R$. solanacearum but it was inferior to $300 \mathrm{ppm}$ chitosan with acetic acid, $400 \mathrm{ppm}$ chitosan with acetic acid, and 500 ppm chitosan with acetic acid. The results indicate that the zones of inhibition produced by these chitosan with acetic acid treatments were not only due to the effect of $1 \%$ acetic acid alone. The addition of $1 \%$ acetic acid to chitosan enhances its property to become antimicrobial against the pathogen used. This results to the production of larger zones of inhibition than when either of them is applied independently.

No et al. (2002) reported that the antibacterial activity of chitosan was inversely affected by $\mathrm{pH}(\mathrm{pH} 4.5-5.9)$, with higher activity at lower $\mathrm{pH}$ value. Solubility of chitosan increases with decreasing $\mathrm{pH}$ (Mohy et al., 2008). The amino groups of chitosan become ionized at $\mathrm{pH}$ below 6 and carry a positive charge. The increase of the amino group substitution on the chitosan chains increases the positively cationic nature of chitosan in acidic solutions which could lead to a greater chance of an interaction between the chitosan and the negatively charged cell walls of the microorganisms.

\section{In vitro comparative efficacy of 3 chitosan sources against $R$. solanacearum}

All three kinds of 200 ppm crab chitosan from Japan, VSU, and China, in $\mathrm{dH}_{2} \mathrm{O}$, had no direct antimicrobial property against $\mathrm{R}$. solanacearum in vitro at 2, 4 and 6 days after inoculation (DAI). This included the China chitosan which was said to be water soluble. No zones of inhibition were observed on the inoculated plates (Table 2; Figure 4). When dissolved in acetic acid, however, they all produced clear zones of inhibition measuring from $5.47 \mathrm{~mm}$ to $6.83 \mathrm{~mm}$ during the three-day observation period. 


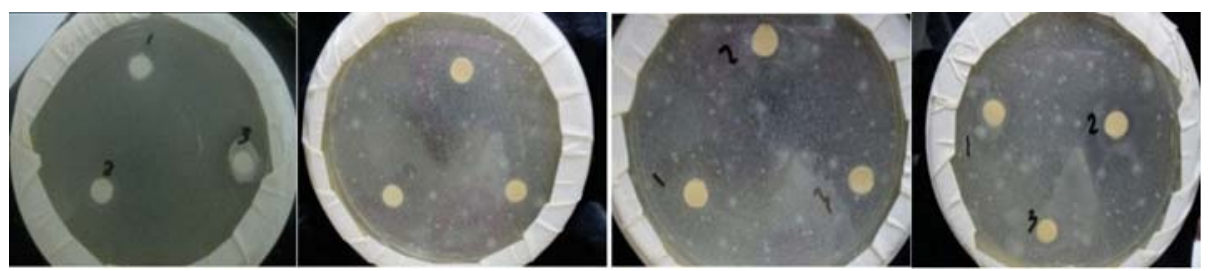

Water alone

100 ppm chitosan

200 ppm chitosan

300 ppm chitosan

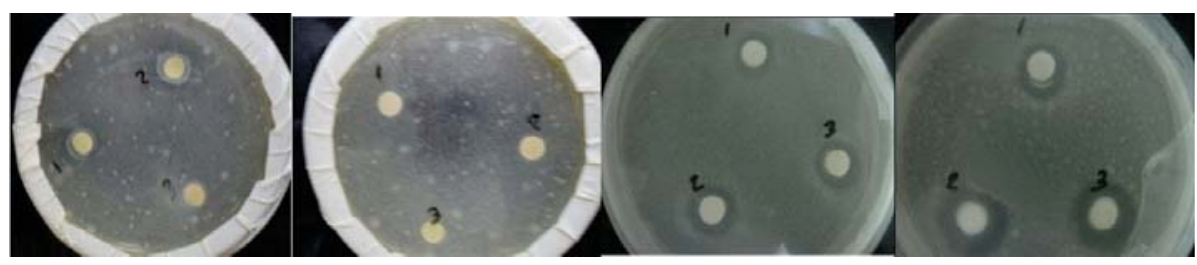

400 ppm chitosan

500 ppm chitosan

100 ppm chitosan w/ AA 200 ppm chitosan w/ AA

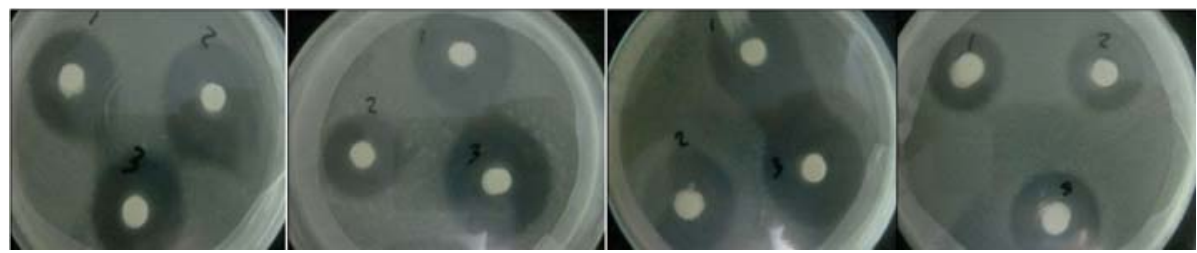

300 ppm chitosan w/AA 400 ppm chitosan w/AA 500 ppm chitosan w/ AA

$1 \%$ acetic acid

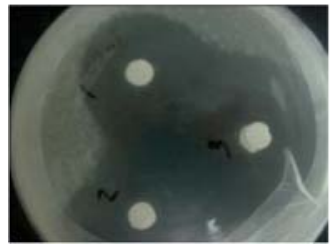

300 ppm steptomycin

Figure 3. Inhibition zone in plates grown with $R$. solanacearum applied with different concentrations of chitosan with and without acetic acid, $1 \%$ acetic acid, and streptomycin.

The zones of inhibition produced by the three chitosan were even significantly bigger than Streptomycin antibiotic and $2000 \mathrm{ppm}$ acetic acid alone (positive controls). The inhibition zones produced by $200 \mathrm{ppm}$ Streptomycin was smaller (3.3, 3.5, and $3.5 \mathrm{~mm}$ at 2, 4 , and 6 DAI, respectively).

\section{In Vivo Evaluation of Different Chitosan Concentrations for Bacterial Wilt Control}

Chitosan dissolved in acetic acid at 200, 300, 400, and 500 ppm concentrations produced longer incubation periods, lesser percent infected plants, and lowest disease severity ratings compared to the same chitosan concentrations dissolved in water, streptomycin (antibiotic), acetic acid alone, and $\mathrm{dH}_{2} \mathrm{O}$ alone. Two hundred (200) ppm chitosan with acetic acid treated plants showed the longest incubation period (Figure 5), lowest percent infection (Table 3), and disease severity rating (Figure 6). Two hundred ppm chitosan/acetic acid provided the highest percentage survival among the treatments (Figure 7). 
Table 1. Zone of inhibition of Ralstonia solanacearum as affected by different concentrations of chitosan with and without acetic acid, $1 \%$ acetic acid, and streptomycin at 2, 4, and 6 days after treatment. ${ }^{1}$

\begin{tabular}{llcl}
\hline Treatments & \multicolumn{3}{c}{ Zone Of Inhibition $(\mathrm{Mm})^{2}$} \\
\cline { 2 - 4 } Sterile water (negative control) & \multicolumn{3}{c}{ Days After Treatment } \\
\cline { 2 - 4 } $100 \mathrm{ppm}$ chitosan/ $/ \mathrm{dH}_{2} \mathrm{O}$ & $0.0^{\mathrm{f}}$ & $0.0^{\mathrm{e}}$ & $0.0^{\mathrm{e}}$ \\
$200 \mathrm{ppm}$ chitosan $/ \mathrm{dH}_{2} \mathrm{O}$ & $0.0^{\mathrm{f}}$ & $0.0^{\mathrm{e}}$ & $0.0^{\mathrm{e}}$ \\
$300 \mathrm{ppm}$ chitosan/ $\mathrm{dH}_{2} \mathrm{O}$ & $0.0^{\mathrm{f}}$ & $0.0^{\mathrm{e}}$ & $0.0^{\mathrm{e}}$ \\
$400 \mathrm{ppm}$ chitosan $/ \mathrm{dH}_{2} \mathrm{O}$ & $0.0^{\mathrm{f}}$ & $0.0^{\mathrm{e}}$ & $0.0^{\mathrm{e}}$ \\
$500 \mathrm{ppm}$ chitosan/ $\mathrm{dH}_{2} \mathrm{O}$ & $0.0^{\mathrm{f}}$ & $0.0^{\mathrm{e}}$ & $0.0^{\mathrm{e}}$ \\
$100 \mathrm{ppm}$ chitosan/AA & $2.0^{\mathrm{e}}$ & $2.6^{\mathrm{d}}$ & $2.7^{\mathrm{d}}$ \\
$200 \mathrm{ppm}$ chitosan/AA & $4.2^{\mathrm{cd}}$ & $4.5^{\mathrm{c}}$ & $4.6^{\mathrm{c}}$ \\
$300 \mathrm{ppm}$ chitosan/AA & $6.2^{\mathrm{b}}$ & $6.8^{\mathrm{b}}$ & $7.0^{\mathrm{b}}$ \\
$400 \mathrm{ppm}$ chitosan/AA & $5.7^{\mathrm{bc}}$ & $6.1^{\mathrm{b}}$ & $6.4^{\mathrm{b}}$ \\
$500 \mathrm{ppm}$ chitosan/AA & $5.3^{\mathrm{bc}}$ & $6.3^{\mathrm{b}}$ & $6.3^{\mathrm{b}}$ \\
$1 \% \mathrm{AA}$ & $3.7^{\mathrm{d}}$ & $4.2^{\mathrm{c}}$ & $4.2^{\mathrm{cd}}$ \\
$300 \mathrm{ppm}$ streptomycin (positive control) & $11.2^{\mathrm{a}}$ & $11.5^{\mathrm{a}}$ & $11.5^{\mathrm{a}}$ \\
\hline $\mathrm{CV}(\%)$ & 33.68 & 27.89 & 27.74 \\
\hline
\end{tabular}

${ }^{1}$ Means in a column followed by common letter/s are not significantly different at $5 \%$ HSD.

${ }^{2}$ Zone of inhibition was measured from the edge of the disc up to the end of the cleared area of bacterial growth.

Table 2. Zone of inhibition of Ralstonia solanacearum as affected by $200 \mathrm{ppm}$ of different kinds of chitosan dissolved in $\mathrm{dH}_{2} \mathrm{O}$ or acetic acid, $2000 \mathrm{ppm}$ acetic acid and $200 \mathrm{ppm}$ streptomycin at 2,4 , and 6 days after treatment.

\begin{tabular}{lccc}
\hline \multirow{2}{*}{ Treatments } & \multicolumn{3}{c}{ Inhibition Zone $(\mathrm{Mm})^{2}$} \\
\cline { 2 - 4 } & \multicolumn{3}{c}{ Days after treatment } \\
\cline { 2 - 4 } & 2 & 4 & 6 \\
\hline Sterile dH $\mathrm{d}_{2} \mathrm{O}$ (negative control) & $0.00^{\mathrm{c}}$ & $0.00^{\mathrm{c}}$ & $0.00^{\mathrm{c}}$ \\
$200 \mathrm{ppm}$ Streptomycin (positive control) & $3.30^{\mathrm{b}}$ & $3.50^{\mathrm{b}}$ & $3.50^{\mathrm{b}}$ \\
$200 \mathrm{ppm}$ Japan Chitosan/ $\mathrm{dH}_{2} \mathrm{O}$ & $0.00^{\mathrm{c}}$ & $0.00^{\mathrm{c}}$ & $0.00^{\mathrm{c}}$ \\
$200 \mathrm{ppm}$ VSU Chitosan/ $\mathrm{dH}_{2} \mathrm{O}$ & $0.00^{\mathrm{c}}$ & $0.00^{\mathrm{c}}$ & $0.00^{\mathrm{c}}$ \\
$200 \mathrm{ppm}$ China Chitosan/dH $2 \mathrm{O}$ & $0.00^{\mathrm{c}}$ & $0.00^{\mathrm{c}}$ & $0.00^{\mathrm{c}}$ \\
$200 \mathrm{ppm}$ Japan Chitosan/AA & $6.00^{\mathrm{a}}$ & $6.73^{\mathrm{a}}$ & $6.83^{\mathrm{a}}$ \\
$200 \mathrm{ppm}$ VSU Chitosan/AA & $5.80^{\mathrm{a}}$ & $6.17^{\mathrm{a}}$ & $6.30^{\mathrm{a}}$ \\
$200 \mathrm{ppm}$ China Chitosan/AA & $5.47^{\mathrm{a}}$ & $6.07^{\mathrm{a}}$ & $6.23^{\mathrm{a}}$ \\
$2000 \mathrm{ppm} \mathrm{AA}$ & $2.83^{\mathrm{b}}$ & $2.83^{\mathrm{b}}$ & $3.00^{\mathrm{b}}$ \\
\hline $\mathrm{CV}(\%)$ & 8.37 & 7.22 & 7.06 \\
\hline
\end{tabular}

${ }^{1}$ Means in a column followed by common letter/s are not significantly different at $5 \%$ HSD.

${ }^{2}$ Zone of inhibition was measured from the edge of the disc up to the end of the cleared area of bacterial growth. 


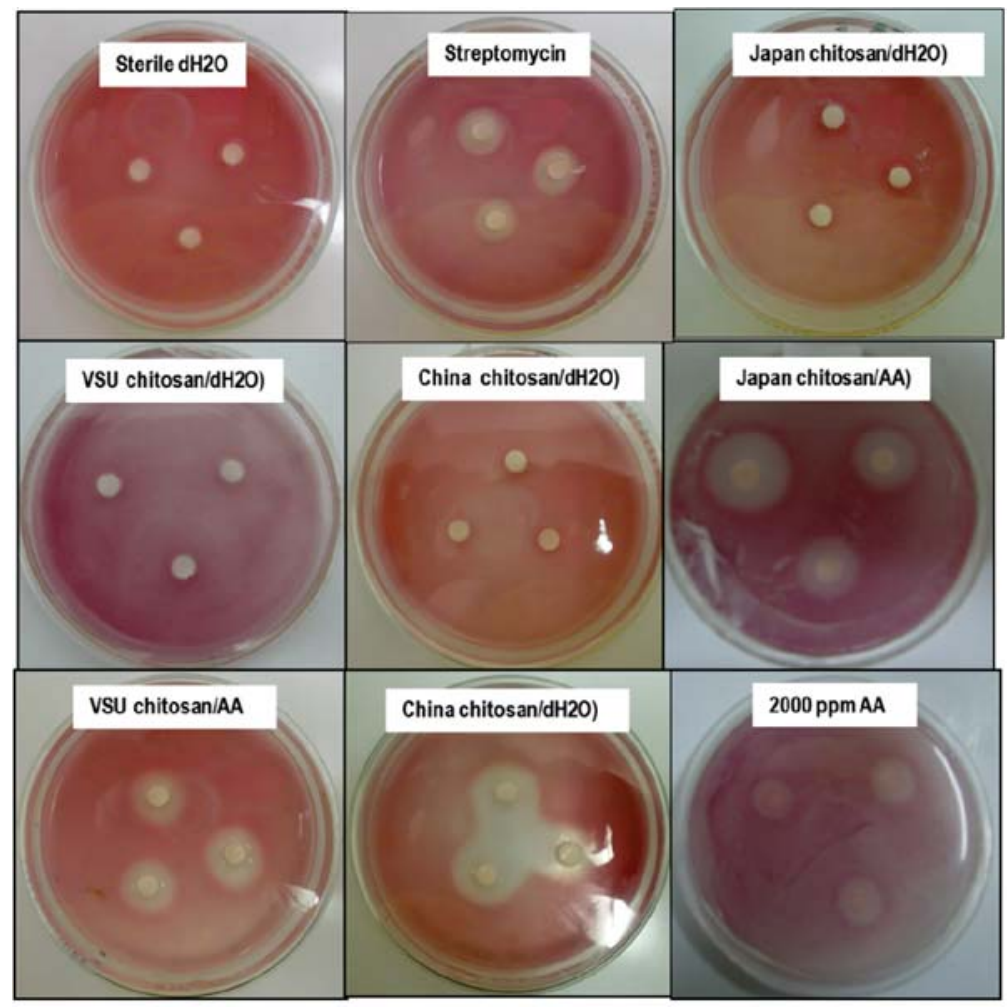

Figure 4. Inhibition zone in plates grown with $\mathrm{R}$. solanacearum applied with sterile $\mathrm{dH}_{2} \mathrm{O}$ (- check), 200 ppm Streptomycin (+ check), different kinds of 200 ppm chitosan dissolved in $\mathrm{dH}_{2} \mathrm{O}$, different kinds of $200 \mathrm{ppm}$ chitosan dissolved in $2000 \mathrm{ppm}$ acetic acid, and 2000 ppm acetic acid alone (+ check).

Table 3. Percentage of infected tomato seedlings as affected by different chitosan concentrations with and without acetic acid at 7, 15, 21, and 29 days after treatment.

\begin{tabular}{lllcc}
\hline Treatments & \multicolumn{4}{c}{ Percent Infection ${ }^{1}$} \\
\cline { 2 - 5 } & \multicolumn{4}{c}{ Days After Inoculation } \\
& \multicolumn{1}{c}{15} & 21 & 29 \\
\hline Sterile water & $43.3 \mathrm{abc}$ & $90.0 \mathrm{a}$ & $100.0 \mathrm{a}$ & $100.0 \mathrm{a}$ \\
$100 \mathrm{ppm}$ chitosan/ $\mathrm{dH}_{2} \mathrm{O}$ & $50.0 \mathrm{ab}$ & $73.3 \mathrm{ab}$ & $83.3 \mathrm{ab}$ & $83.3 \mathrm{ab}$ \\
$200 \mathrm{ppm}$ chitosan/ $\mathrm{dH}_{2} \mathrm{O}$ & $30.0 \mathrm{abcd}$ & $60.0 \mathrm{abc}$ & $63.3 \mathrm{bc}$ & $66.7 \mathrm{abc}$ \\
$300 \mathrm{chitosan}$ alone $/ \mathrm{dH}_{2} \mathrm{O}$ & $46.7 \mathrm{abc}$ & $76.7 \mathrm{ab}$ & $76.7 \mathrm{ab}$ & $76.7 \mathrm{ab}$ \\
$400 \mathrm{ppm}$ chitosan/ $\mathrm{dH}_{2} \mathrm{O}$ & $56.7 \mathrm{a}$ & $70.0 \mathrm{abc}$ & $76.7 \mathrm{ab}$ & $80.0 \mathrm{ab}$ \\
$500 \mathrm{ppm}$ chitosan/ $/ \mathrm{dH}_{2} \mathrm{O}$ & $60.0 \mathrm{a}$ & $73.3 \mathrm{ab}$ & $76.7 \mathrm{ab}$ & $76.7 \mathrm{ab}$ \\
$100 \mathrm{ppm}$ chitosan/AA & $30.0 \mathrm{abcd}$ & $73.3 \mathrm{ab}$ & $76.7 \mathrm{ab}$ & $80.0 \mathrm{ab}$ \\
$200 \mathrm{ppm}$ chitosan/AA & $13.3 \mathrm{~cd}$ & $23.3 \mathrm{c}$ & $30.0 \mathrm{c}$ & $40.0 \mathrm{c}$ \\
$300 \mathrm{ppm}$ chitosan/AA & $0.0 \mathrm{~d}$ & $33.3 \mathrm{bc}$ & $53.3 \mathrm{bc}$ & $63.3 \mathrm{bc}$ \\
$400 \mathrm{ppm}$ chitosan/AA & $16.7 \mathrm{bcd}$ & $56.7 \mathrm{abc}$ & $63.3 \mathrm{bc}$ & $63.3 \mathrm{bc}$ \\
$500 \mathrm{ppm}$ chitosan/AA & $16.7 \mathrm{bcd}$ & $63.3 \mathrm{abc}$ & $80.0 \mathrm{ab}$ & $83.3 \mathrm{ab}$ \\
$1 \% \mathrm{AA}$ & $3.3 \mathrm{~d}$ & $46.7 \mathrm{abc}$ & $56.7 \mathrm{bc}$ & $56.7 \mathrm{bc}$ \\
$300 \mathrm{ppm}$ streptomycin & $60.0 \mathrm{a}$ & $83.3 \mathrm{a}$ & $86.7 \mathrm{a}$ & $86.7 \mathrm{a}$ \\
\hline $\mathrm{CV}(\%)$ & 63.9 & 26.4 & 16.7 & 15.5 \\
\hline
\end{tabular}

${ }^{1}$ Means in a column followed by common letter/s are not significantly different at 5\% HSD. 


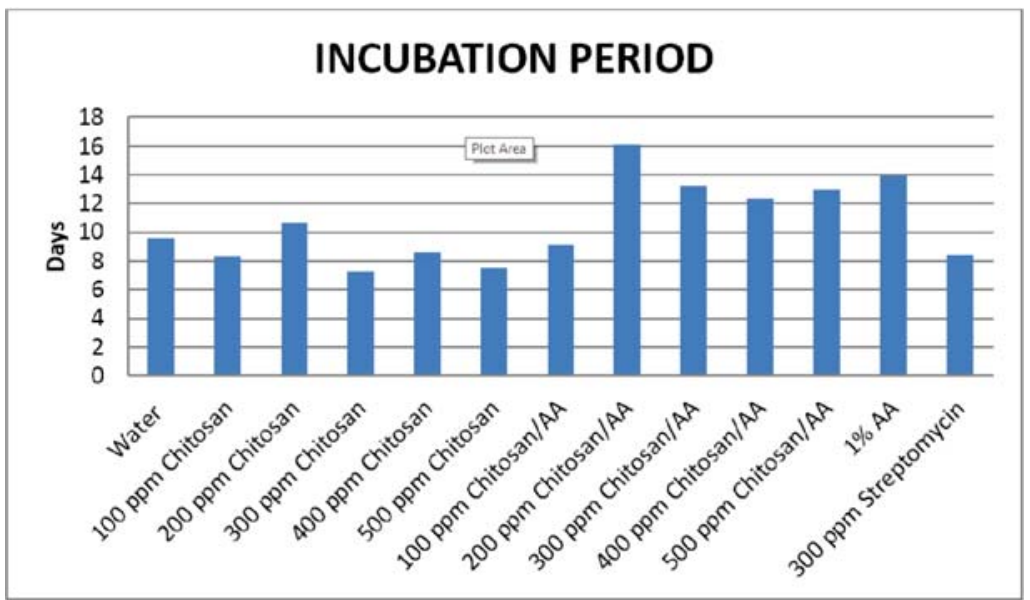

Figure 5. Bacterial wilt incubation period as affected by varying chitosan concentrations.

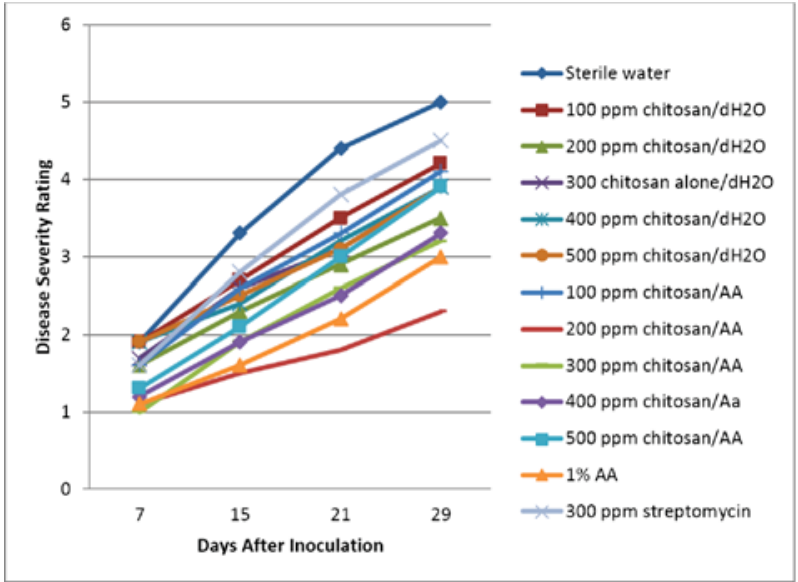

Figure 6 . Bacterial wilt disease severity ratings as affected by different chitosan concentrations with and without acetic acid at 7, 15,21, and 29 days after treatment.

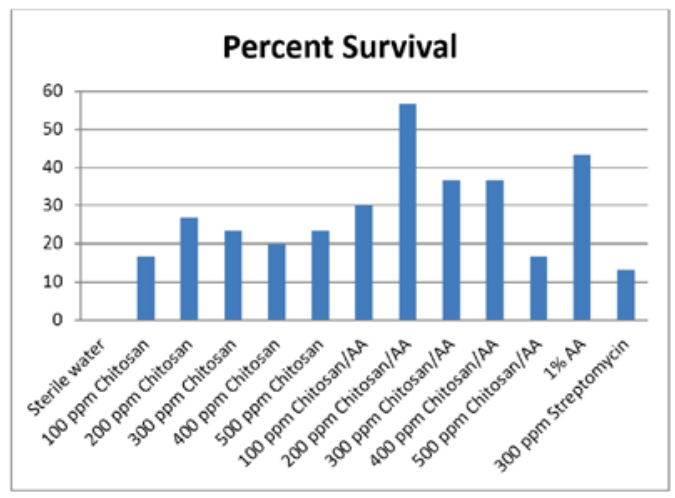

Figure 7. Percent survival of tomato seedlings as affected by different chitosan concentrations with and without acetic acid. 
Percent infection and disease severity ratings of tomato plants treated with the chitosan $/ \mathrm{dH}_{2} \mathrm{O}$ treatments were generally lesser than those of tomato plants treated with $\mathrm{dH}_{2} \mathrm{O}$ alone although the values are not significantly different. This indicates that although the chitosan alone treatments had no direct antimicrobial property against the bacterial wilt pathogen in vitro, they had reduced the percentage infected plants as well as the disease severity a little. This action of the chitosan alone treatments most likely was due to its ability to induce resistance in plants. The level of control, however, was not that high since there was also a high pathogen pressure to the artificially inoculated plants.

In the in vitro data, $200 \mathrm{ppm}$ chitosan/acetic acid treatment showed smaller zone of inhibition compared to $300 \mathrm{ppm}$ chitosan/ acetic acid. On the treated plants, however, it offered the best protection against bacterial wilt among the treatments which means that the mode of action of $200 \mathrm{ppm}$ chitosan/acetic acid on tomato plants was not just due to its direct antimicrobial property against the pathogen, but also due to its ability to induce resistance in tomato against bacterial wilt. Chung et al., 2003 as cited by Hadrami et al., 2010 reported that chitosan is often used in plant disease control as a powerful elicitor rather than a direct antimicrobial or toxic agent. Its direct toxicity remains dependent on properties such as the concentration applied, the molecular weight, degree of acetylation, solvent, $\mathrm{pH}$, and viscosity.

\section{Evaluation of Effective Application Method for the Control of BacterialWilt}

All methods of chitosan/acetic acid application whether root dipped, drenched, sprayed or a combination of these methods produced a significantly lower percentage infection compared to the untreated plants and were generally more effective than streptomycin treatments and acetic acid treatments (Table 4). The data further shows that dipping the roots once in $200 \mathrm{ppm}$ chitosan with acetic acid was enough to protect the plants from bacterial wilt since percentage infection was just the same as dipping once and weekly drenching and even gave lower percent infection than drenching and spraying at weekly interval and dipping and weekly spraying. One time root dipping was enough to delay infection since infection was recorded as late, i.e., at 35 days after inoculation.

Chitosan when weekly sprayed to the leaves of tomato was able to reduce percent infection although lesser effective than root dipping. This is because it was not able to get in direct contact with the pathogen (unlike the root dipping) and was not able to exert its antimicrobial property to the pathogen and therefore its mode of action was most likely as an inducer of resistance to tomato against bacterial wilt.

Streptomycin root dip gave comparable percentage infection to chitosan/acetic acid root dip especially at 42 DAI but it succumbed to the disease earlier than chitosan/acetic acid root dip. Furthermore, the chitosan/acetic acid treatments regardless of the method of application showed slower increase in percent infection over time than the Streptomycin treatments. Percent infected plants in Streptomycin one time dipping and weekly drenching and Streptomycin dipping and weekly spraying, as well as dipping and weekly spraying, although lesser than the untreated plants, were not significantly different at $5 \%$ level.

In terms of the percentage surviving plants, one time chitosan root dipping before transplanting, one time chitosan root dipping with weekly drenching, and one time streptomycin root dipping had the highest percent survival ( $90 \%$ at $35 \mathrm{DAI}$ ) followed by dipping once with weekly spraying $(83.33 \%$; Table 5$)$. This again implies that one time root dipping to $200 \mathrm{ppm}$ chitosan with acetic acid was enough to protect the plants from bacterial wilt infection. All the chitosan treatments produced to significantly higher percent survival, together with one time root dipping with streptomycin. 
Table 4. Percentage of infected tomato seedlings as affected by varying treatment application of 200 ppm chitosan with acetic acid at $7,15,21,28,35$, and 42 days after treatment.

\begin{tabular}{|c|c|c|c|c|c|c|}
\hline \multirow{3}{*}{ Treatments } & \multicolumn{6}{|c|}{ Percent Infection } \\
\hline & \multicolumn{6}{|c|}{ Days after inoculation } \\
\hline & 7 & 14 & 21 & 28 & 35 & 42 \\
\hline Sterile $\mathrm{dH}_{2} \mathrm{O}$ ( negative control) & $16.67^{\mathrm{a}}$ & $26.67^{a}$ & $26.67^{a}$ & $36.67^{a}$ & $56.67^{\mathrm{a}}$ & $63.33^{a}$ \\
\hline Chitosan, root dip once & $0.00^{\mathrm{b}}$ & $0.00^{\mathrm{d}}$ & $0.00^{c}$ & $0.00^{\mathrm{d}}$ & $10.00^{\mathrm{bc}}$ & $13.33^{\mathrm{bcc}}$ \\
\hline Chitosan, weekly drenched & $0.00^{\mathrm{b}}$ & $10.00^{\mathrm{abcd}}$ & $10.00^{\mathrm{abc}}$ & $13.33^{\mathrm{abc}}$ & $16.67 \mathrm{bc}$ & $20.00^{\mathrm{bcc}}$ \\
\hline Chitosan, weekly sprayed & $3.33^{\mathrm{b}}$ & $6.67^{\mathrm{bcd}}$ & $6.67^{b c}$ & $6.67^{\mathrm{cd}}$ & $10.00^{\mathrm{bc}}$ & $20.00^{\mathrm{bcc}}$ \\
\hline Chitosan, root dip and weekly drenched & $3.33^{\mathrm{b}}$ & $3.33^{\mathrm{cd}}$ & $3.33^{b c}$ & $6.67^{\mathrm{cd}}$ & $6.67^{c}$ & $13.33^{\mathrm{bcc}}$ \\
\hline Chitosan, root dip and weekly sprayed & $0.00^{\mathrm{b}}$ & $0.00^{\mathrm{d}}$ & $0.00^{c}$ & $10.00^{\mathrm{cd}}$ & $16.67^{\mathrm{bc}}$ & $16.67^{\mathrm{cd}}$ \\
\hline Streptomycin, root dip once & $6.67 \mathrm{ab}$ & $13.33^{\mathrm{abc}}$ & $13.33^{\mathrm{ab}}$ & $13.33 \mathrm{bc}$ & $13.33 \mathrm{bc}$ & $13.13 \mathrm{~d}$ \\
\hline Streptomycin, weekly drenched & $3.33^{\mathrm{b}}$ & $10.00^{\mathrm{abcd}}$ & $10.00^{\mathrm{abc}}$ & $16.67^{\mathrm{abc}}$ & $20.00^{\mathrm{bc}}$ & $26.67^{\mathrm{bcc}}$ \\
\hline Streptomycin, weekly sprayed & $0.00^{\mathrm{b}}$ & $6.67^{\mathrm{bcd}}$ & $6.67^{\mathrm{bc}}$ & $6.67^{\mathrm{cd}}$ & $23.33^{\mathrm{bc}}$ & $30.00^{\mathrm{bcc}}$ \\
\hline Streptomycin, root dip and weekly drenched & $16.67^{\mathrm{a}}$ & $26.67^{\mathrm{a}}$ & $26.67^{\mathrm{a}}$ & $33.33^{\mathrm{ab}}$ & $36.67^{\mathrm{ab}}$ & $40.00^{\mathrm{ab}}$ \\
\hline Streptomycin, root dip and weekly sprayed & $6.67^{\mathrm{ab}}$ & $16.67^{\mathrm{ab}}$ & $13.33^{\mathrm{ab}}$ & $16.67 \mathrm{abc}$ & $26.67 \mathrm{bc}$ & $36.67^{\mathrm{abc}}$ \\
\hline $2000 \mathrm{ppm}$ Acetic acid & $0.00^{\mathrm{b}}$ & $10.00^{\mathrm{abc}}$ & $10.00^{\mathrm{ab}}$ & $16.67^{\mathrm{abc}}$ & $33.33^{\mathrm{ab}}$ & $36.67^{\mathrm{abc}}$ \\
\hline CV $(\%)$ & 70.71 & 45.12 & 45.69 & 37.55 & 36.57 & 28.32 \\
\hline
\end{tabular}

${ }^{1}$ Means in a column followed by common letter/s are not significantly different at $5 \%$ HSD.

In a similar study conducted by Piamonte (2011), two, three, and four sprays of elicitors were comparable in protecting rice against rice blast disease caused by Pyricularia grisea. The third and fourth sprays are no longer necessary since two sprays are already enough to protect rice against rice blast. Sticher et al., (1997) stated that once resistance is induced or SAR is activated in plants against a specific pathogen, it retains its efficacy for weeks or even for the whole cropping season.

Table 5. Percent survival of inoculated tomato seedlings as affected by different application methods of chitosan with acetic acid (200 ppm) and Streptomycin $(200 \mathrm{ppm})$ at 35 days after inoculation.

\begin{tabular}{lc}
\hline Treatments & Percent Survival \\
\cline { 2 - 2 } & 42 days after inoculation \\
\hline Sterile $\mathrm{dH}_{2} \mathrm{O}$ (negative control) & $36.67^{\mathrm{b}}$ \\
Chitosan, root dip once & $90.00^{\mathrm{a}}$ \\
Chitosan, weekly drenched & $80.00^{\mathrm{a}}$ \\
Chitosan, weekly sprayed & $80.00^{\mathrm{a}}$ \\
Chitosan, root dip and weekly drenched & $90.00^{\mathrm{a}}$ \\
Chitosan, root dip and weekly sprayed & $83.33^{\mathrm{a}}$ \\
Streptomycin, root dip once & $90.00^{\mathrm{a}}$ \\
Streptomycin, weekly drenched & $73.33^{\mathrm{ab}}$ \\
Streptomycin, weekly sprayed & $73.33^{\mathrm{ab}}$ \\
Streptomycin, root dip and weekly drenched & $60.00^{\mathrm{ab}}$ \\
Streptomycin, root dip and weekly sprayed & $63.33^{\mathrm{ab}}$ \\
2000 ppm 0f Acetic acid & $63.33^{\mathrm{ab}}$ \\
\hline CV (\%) & 10.37 \\
\hline
\end{tabular}

${ }^{1}$ Means in a column followed by common letter/s are not significantly different at 5\% HSD.

\section{CONCLUSIONS AND IMPLICATIONS}

Chitosan possessed direct antimicrobial property against Ralstonia solanacearum when dissolved in acetic acid. In vitro inhibition of chitosan/acetic acid was best at $300 \mathrm{ppm}$. In inoculated tomato plants, $200 \mathrm{ppm}$ chitosan/acetic acid produced the longest disease incubation period, lowest percentage infection, lowest disease severity rating, and highest percentage survival. Chitosan also showed resistance elicitor property in tomato for bacterial wilt control. The action of $200 \mathrm{ppm}$ chitosan/acetic acid treatments on the tomato plants was due to a dual effect, i.e., as a direct antimicrobial and as an elicitor of 
resistance. Regardless of source, 200 ppm chitosan dissolved in acid inhibited Ralstonia solanacearum and the zone of inhibition was significantly bigger than that of $200 \mathrm{ppm}$ streptomycin and acetic acid alone. All application methods were effective in controlling bacterial wilt but one time root dipping to $200 \mathrm{ppm}$ chitosan dissolved in acetic acid before transplanting was enough to protect the plants against the disease. Field trials on this are recommended but farmers may try this method in their farms.

\section{ACKNOWLEDGMENT}

The authors would like to thank the Commission on Higher Education (CHED) for the research funds. Acknowledgment is also given to Southern Leyte State University through Dr. Dewoowoogen Baclayon for facilitating fund transfers and other miscellaneous activities of the project.

\section{REFERENCES}

AMBORABE, B. E., J. BONMORT, P. FLEAURAT-LESSARD, and G. ROBLIN. 2008. Early events induced by chitosan on plant cells. J. Microbiol. Biotechnol; 18 (10):1729-34. http://www.ncbi.nlm.nih.gov / pubmed/18515832

BADE, M. L. and R. L. WICK. 1988. Protecting crops and wildlife with chitin and chitosan. In Biologically Active Natural Products: Potential Use in Agriculture, Cutler, H. G. (ed), pp.451-469. American Chemical Society, Washington D.C.

CHAMPOISEAU, P. G.,J. B. JONES, and C. ALLEN. 2009. Ralstonia solanacearum race 3 biovar 2 causes tropical losses and temperate anxieties.online.PlantHealth Progressdoi:10.1094/ PHP2009031301RV._http://plantpath.ifas.ufl.edu /rsol/Practice CV/Champoiseau_PublicationGB.html

HADRAMI, A. E., L. R. ADAM, I. E. HADRAMI, and F. DAYAF. 2010. Chitosan in Plant Protection. University of Manitoba, Department of Plant Science, 222, Agriculture Building, Winnipeg, Manitoba, R3T 2N2, Canada. Online.

HAYWARD, A.C.1985. Bacterial wilt caused by Pseudomonas solanacearum in Asia and Australia: An Overview: Proceedings of an International Workshop held at PCARRD, Los Baños, Philippines. online. http://aciar.gov.au/files/node/ 2299/bacterial_wilt disease_in_asia_and_the_south_pacif_17356.pdf

MOHY M.S., I. ELDIN, E.A. SOLIMAN, A.I. HASHE and T.M. TAMER. 2008. Chitosan Modified Membranes for Wound Dressing Applications: Preparations, Characterization and Bio-Evaluation. Trends Biomater Artif. Organs 22(3): 158-168.

MODINA, I. M. 2007.Antimicrobial Property of Chitosan and Induction of Systemic Acquired Resistance for the control of Rice Bacterial Blight caused by Xanthomonas oryzaepv oryzae. Unpublished Undergraduate Thesis. Leyte State University. 51pp

NIÑO M. C.2009.Pathogenicity, Characterization, Identification of a bacterium of Abaca and Its Control through Elicitors of Resistance

NO, H. K., N. Y. PARK, S. H. LEE, and S. P. MEYERS. 2002. Antibacterial activity of chitosans and chitosan oligomers with different molecular weights. http://www.mendeley.com/catalog/antibacterial-activity-chitosans-chitosanoligomers -different-molecular-weights/.

PERSLEY, G.J. 1985. Bacterial Wilt Disease in Asia and the South Pacific:Proceedings of an International Workshop held at PCARRD, Los Baños, Philippines.online. http://aciar.gov.au/files/node/2299/ bacterial_wiltdisease_in_asia_and_the_south _pacif_17356.pdf

PIAMONTE, R. T. 2011. Antifungal Property of Chemical Elicitors and Induction of Systemic Acquired Resistance (SAR) for the Control of Rice Blast Caused by Pyriculariagrisea Sacc. 
RYALS, J.A., U.H. NEVERSCHWANDER,M.G. WILLITIS, A. MOLINA, H.Y. STEINER, and M.D. HUNT. 1996. Systemic Acquired Resistance. The Plant Cell.8:1809-1819.online.http://www.plantcell.org/ content/8/10/1809.full.pdf

STICHER, L., B. MAUCH-MANI and J.P. METRAUX. 1997. Systemic acquired resistance. Annu Rev Phytopathol. 35: 235-270.

WALKER, J.F., S. MORRIS, P. BROWN and A. GRACIE. 2004. Evaluation for Potential of Chitosan to Enhance Plant Defence:A Report for the Rural Industries Research and Development Corporation. online. http://www.peracto.com. $\mathrm{au} /$ publications/chitosan-evaluation.pdf

WANG, J.F. and C.H. LIN. 2005. Integrated Management of Tomato Bacterial Wilt. AVRDC publication 05-615. AVRDC-The World Vegetable Center. PO Box 42, Shanhua, Tainan, Taiwan 741, ROC 